\title{
EFFECT OF DIETARY PROTEIN LEVELS, SEX AND AGE ON TIBIAE CHARATERISTICS IN TWO STRAINS OF BROILER CHICKENS**
}

\author{
Z. Pavlovski ${ }^{1^{*}}$, N. Nikolova ${ }^{2}$, D. Vitorović ${ }^{3}$, Z. Škrbić $^{1}$, M. Lukić ${ }^{1}$ \\ ${ }^{1}$ Institute for Animal Husbandry, Belgrade-Zemun, Serbia \\ ${ }^{2}$ Institute for Animal Husbandry, Skopje, Macedonia \\ ${ }^{3}$ Agriculture Faculty, Zemun, Serbia \\ *Corresponding author, e-mail: zlaticapav@yahoo.com \\ ** Original scientific paper. Research financed by the Ministry of Science of Republic of \\ Serbia, Project TR6885
}

\begin{abstract}
Cobb 500 and Hubbard Classic broiler chicks were reared on the floor during seven weeks of fattening. Chicks, of each strain, were divided in two groups (160 chicks in group) and feed with two isocaloric diets differed in protein levels. The contents of crude protein in the diets 1 , were $23 \%(1-2$ weeks of age), $22 \%$ (3. week), $21 \%$ (4-6 weeks), $18 \%$ (7. week) and in the diets 2 were $22 \%$ ( $1-2$ weeks), $21 \%$ (3. week), $20 \%$ ( $4-6$ weeks) and $17 \%$ (7. week of age). At days 35, 42 and 49, 10 male and 10 female chicks were sacrificed from both strain and both group. The right tibiae were removed and prepared for analysis. Bone breaking force were determined by three-point-bending test at the midlength. Geometrical properties were obtained by measuring of outside and inside antero-posterior and lateromedial diameters, at the middiaphyseal transverse section of each tibia. These data were used to calculated of bones cross sectional cortical area and cross sectional medullar area.

The obtained results showed that cross sectional cortical area and cross sectional medullar area increased with age and were influenced by strain and sex but not by dietary protein levels. Hubbard Classic chicks had higher cortical and lower medullar area than Cobb 500 chicks. The breaking force and ratio cortical/medullar area were significantly $(p<0.05)$ greater in male than in female chicks of each strain. The male chicks of both strain, fed the diets 2, during six weeks of fattening, had the largest tibiae breaking force $(47.0-50.0 \mathrm{~kg})$ but the differences were not significant. Geometrical and mechanical characteristics of broilers tibiae were notsignificantly influenced by dietary protein levels.
\end{abstract}


Key words: broilers, bone strength, dietary protein, strain, sex

\section{Introduction and literarure review}

Intensive selection on growth rate of broiler chickens caused shortening of fattening duration. Modern broiler hybrids reach slaughter mass at the age of 41-42 days of age. This is twice as fast than 30 years ago. This fast growth relates mainly to growth of muscle mass. However, growth and development of bones, especially legs is not in accordance with muscle growth. In this way bones could not give necessary support to body. Heart causes weak bones which is manifested in different leg deformations and breaking. Su et al. (1999) stated that leg weakness is serious problem in fast growing broiler chickens, which causes considerable economical losses.

Factors which influence the quality of bone structure can be divided into three main categories: genetic, rearing system and nutrition.

Results stated by Mašić et al., (1992), Kestin and Sorennsen, (1999), Hopić et al. (2001), Reddish and Lilburn (2004) relate to the influence of hereditary basis on strength of chicken bones.

The effect of rearing method was investigated by comparison of floor and cage system of rearing (Vitorović et al. 1988, Vitorović et al., 1992, Vitorović et al., 1995) and lately also by comparison of semi-intensive and aviary system of rearing (Newman and Leeson, 1998).

The effect of nutrition was mainly investigated through sources and presence of calcium and phosphorus in mixtures, as well as their munutal relation. (Guinote and Nys, 1991, Peric et al., 1998). Also, the effect of vitamin D and its metabolites was investigated (Lofton and Soares, 1986; Cruickshank and Sim, 1987; Whitehead, 1996).

Recently, special attention is directed to the efficiency of addition of enzyme phytaze to diets for broilers, on quality of the skeleton. Following authors report on the consequences of addition of phytaze to diets on the bone system of poultry Qian et al. (1996), Radović et al. (2003). Punna $i$ Roland (2001) established positive results in use of phytaze in mixtures for nutrition on bone system of chickens and quality of egg shell in layers.

There is only few papers about the effect of the level of protein in diet on growth and quality of broiler bones. Adeola and Sands (2004) established that content of ashes in tibia of chickens wasn't under the influence of content of crude protein in the diet.

Objective of this paper was to investigate the effect of nutrition with two protein levels on geometrical and mechanical characteristics of tibia in two 
broiler hybrids at different ages.

\section{Material and methods}

Broiler chickens of hybrids Cob 500 and Hubbard Classic were reared on floor with deep litter during 7 weeks of fattening. Chickens of each hybrid were divided into two groups (160 chickens in each group). Groups received two mixtures of same composition which were different only in regard to the level of crude protein. Group 1 was fed mixtures with higher content of crude proteins than group 2. In mixture 1, content of crude proteins was 23 $\%$ (age 1-2 weeks), $22 \%$ (3. week of age), $21 \%$ (4-6 weeks of age) and 18 $\%$ (7. week of age). In mixture 2, content of crude proteins was $22 \%(1-2$ weeks of age), $21 \%$ (3. week of age), $20 \%$ (4-6 weeks of age) and $17 \%$ (7. week of age).

At the age of 35, 42 and 49 days, 10 male and 10 female chickens from each group were sacrificed. Right tibia bones were separated from carcasses, left in freezer for later analysis of bone parameters.

After thawing on room temperature the following was measured on bones: length (from proximal to distal end), exterior $\left(\mathrm{R}_{1}, \mathrm{R}_{2}\right)$ and internal ( $\mathrm{r}_{1}$, $r_{2}$ ) diameters on the center of diaphysis (antero-posterior and lateral-medial).

Based on values of these parameters the following was calculated: cross sectional cortical area of diaphysis and cross sectional medullary area of diaphysis.

Biomechanical bone traits were expressed by two indicators: breaking force $(\mathrm{kg})$ using the device IPNIS with support width of $40 \mathrm{~mm}$ and according to methodology stated by Mašić and Pavlovski (1994) and Vitorović et al. (1995).

Obtained results were processed statistically using the programme Statistica for Windows, by method of variance analysis, and significance of differences between mean values in investigated groups was tested by LSD test.

\section{Results of investigation and discussion}

In table 1 values of geometrical parameters (cross sectional cortical area of diaphysis and cross sectional medullary area of diaphysis) and breaking force of diaphysis of tibia in male and female chickens of hybrids Cobb 500 and Hubbard Classic, at the age of 35, 42 and 49 days, depending on the two levels of crude proteins in mixtures are presented. 
Table 1. Geometrical and mechanical properties of tibia ofmale (M) and female (F) broilers

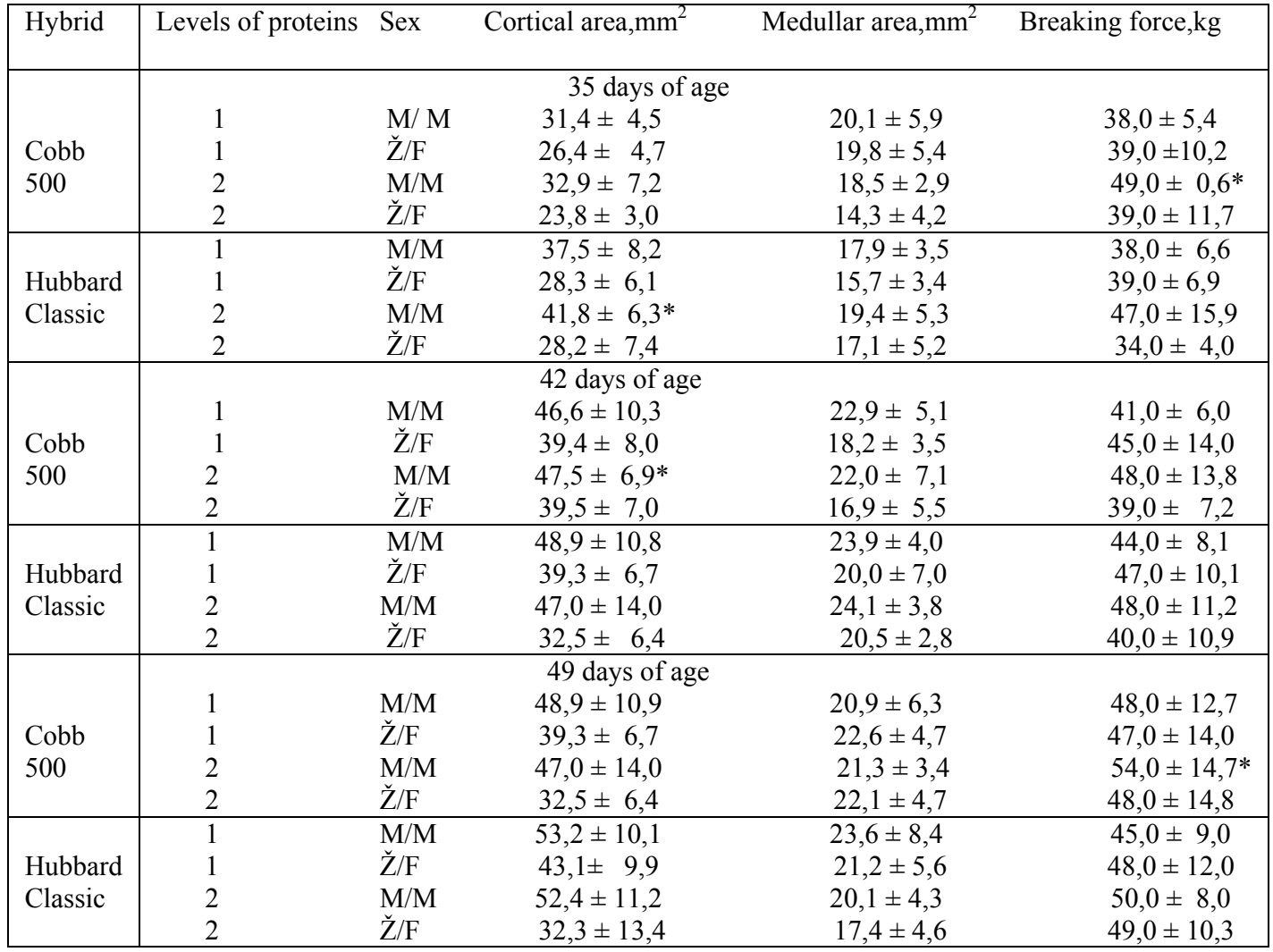

Means \pm Standard deviation; $*$ - $p<0,05$

Significant diferences compared to the control group

Obtained results showed that in both hybrids, tibia bones in male chickens had greater cross sectional cortical area than timiba bones in female chickens. Cross sectional medullary area of diaphysis was also greater in male than in female chickens.

Differences in regard to genetic effect on macroscopic strukture were also demonstrated. Chickens of hybrid Hubbard Classic had higher values of cross sectional cortical area and lower values of cross sectional medullary area of diaphysis compared to Cobb 500 chickens in all investigated ages.

Breaking force of tibia was considerably higher in males than in females 
in both hybrids, and with the age of chickens the value of breaking force increased. At the age of 35 days, breaking force of tibia in female chickens varied from $34-39 \mathrm{~kg}$ and in male chickens from $38-49 \mathrm{~kg}$. At the age of 42 days, breaking force of tibia in female chickens varied from $39-48 \mathrm{~kg}$ and in males from $41-48 \mathrm{~kg}$. At the age of 49 days breaking force of tibia, in female chickens varied from $47-49 \mathrm{~kg}$ and in males $45-54 \mathrm{~kg}$.

Our results on the effect of genotype and sex on traits of leg in broiler chickens are in accordance with results obtained by Mašić et al., (1992), Kestin and Sorennsen, (1999), Hopić et al. (2001), Reddish i Lilburn (2004).

Different level of crude proteins in diet had no significant effect on macroscopic indicators of bone structure of tibia in broiler chickens.

Higher values of breaking force of tibia were measured in chickens fed diets with lower level ofc rude protein in diet (level 2). These differences were established in both sexes and both investigated hybrids. However, statistical significance of these differences is not confirmed. As a possible reason for this fact we could state small number of bones with high variability of this trait. Therefore it can be recommended for future research of the effect of different factors on bone quality in broiler chickens that it is necessary to work on more than ten bones as a sample.

\section{Conclussion}

Age, sex and hereditary basis are factors of greater effect on geometrical and mechanical traits of tibia in broiler chickens than the level of protein in diet. Tibia bones in male chickens had higher cross sectional cortical area and breaking force and lower cross sectional medullary area of diaphysis in comparison to tibia bones of female chickens.

Chickens of hybrid Hubbard Classic, had higher values of cross sectional cortical area and breaking force and lower values of cross sectional medullary area comapred to Cobb 500 chickens, in all investigated ages.

\section{UTICAJ NIVOA PROTEINA, POLA I UZRASTA NA KARAKTERISTIKE GOLENJAČE KOD DVA HIBRIDA BROJLERSKIH PILIĆA}

Z. Pavlovski, N. Nikolova, D. Vitorović, Z. Škrbić, M. Lukić 


\section{Rezime}

U ogledu su korišćeni brojlerski pilići hibrida Cobb 500 i Hubbard Classic gajenih u tovu tokom sedam nedelja. Pilići, oba hibrida su bili podeljeni u dve grupe (160 pilića po grupi) i hranjeni sa dve smeše istog sastava, koje su se razlikovale u nivou sirovih proteina. Sadržaj sirovih proteina u smešama 1 , je iznosio $23 \%$ (u uzrastu 1.2 nedelje), $22 \%$ (3. nedelje), $21 \%$ (4-6 nedelje), $18 \%$ (7. nedelje). Sadržaj sirovih proteina u smešama 2 je iznossio $22 \%$ (1-2 nedelje), $21 \%$ (3. nedelje), $20 \%$ (4-6 nedelje), $17 \%$ (7. nedelje). Žrtvovanje po 10 jedinki muškog i 10 jedinki ženskog pola je izvršeno u uzrastu od 35, 42 i 49 dana, u okviru svake grupe i hibrida. Desna golenjača je odvajana od trupa I korišćena za anlizu. Sila loma je određivana $\mathrm{u}$ testu sa tri tačke oslonca, na sredini dijafize. Geometrijske karakteristike su određivane merenjem spoljašnjih i unutrašnjih prečnika na sredini poprečnog preseka golenjače. Ove vrednosti su korišćene za izračunavanje poprečnog preseka korteksa dijafize golenjače i površinje poprečnog preseka medularne šupljine.

Dobijeni rezultati su pokazali dasu uzrast, pol i nasledna osnova faktori od većeg uticaja na geometrijske i mehaničke osobine golenjače brojlerskih pilića od nivoa sirovih priteina u oborku..Golenjače muških pilića imale su veću površinu poprečnog preseka korteksa i silu loma a manju površinu poprečnog preseka medularne šupljine u odnosu na golenjače ženskih pilića. Pilići hibrida Hubbard Classic, su imali veće vrednosti poprečnog preseka korteksa i sile loma a manje vrednosti poprečnog preseka.

\section{References}

ADEOLA O., SANDS J. (2004): Growth performance, bone mineralization and nutrient retention responses of chicks to dietary crude protein and nonphytate phosphorus concentrations. International Journal of Poultry Science, 3 (9), 563-569.

CRUICKSHANK J., SIM S. (1987): Effects of exess vitamin D3 and cage density on the incidence of leg abnormalities in broiler chickens. Avian Diseases, 1 (2) 332-338.

GUINOTE F., NYS Y. (1991): The effects of a particulate calcium source in broiler breeder hens upon their egg quality, reproductive traits, bone reserves, chick weight and tibia strength characteristics. Arch. Geflugelk., 55 (4), 170-175. 
HOPIĆ S., PAVLOVSKI Z., ŠKRBIĆ Z., LUKIĆ M. (2001): Biomehaničke osobine pilića različitih genotipova. Biotehnologija u stočarstvu, 12 (2-4),3138.

KESTIN S., SORENSEN P. (1999) : Different commercial broiler crosses have different susceptibilities to leg weakness. Poultry Science, 78:10851090.

LOFTON L., SOARES H. (1986) : The effects of vitamin D3 on leg abnormalities in broilers. Poultry Science, 65: 749-756.

MAŠIĆ B., MILOŠEVIĆ N., PAVLOVSKI Z., ANTONIJEVIĆ N., VITOROVIĆ D., (1992) : Čvrstoća metatarzusa kod različitih provenijenci brojlera. Biotehnlogija u stočarstvu, 8 (3-4) 21-26.

MAŠIĆ B., PAVLOVSKI Z. (1994): Mala jata kokoši nosilja u različitim sistemima držanja. Monografija, Naučni institu za stočarstvo, BeogradZemun.

NEWMAN S., LEESON S. (1998) : Effect of housing birds in cages or an aviary system on bone characteristics. Poutry Science, 77: 1492-1496.

PERIĆ L., SUPIĆ B., MILOŠEVIĆ N., RALJIĆ J., VITOROVIĆ D. (1998): Effect of source of phosphorus on the biomechanical characteristics of the bones of broilers. VIII Simpozijum tehnologije stočne hrane, Petrovac na Mlavi, 138-147.

PUNNA S., ROLAND D. (2001.) Influence of dietary phytase supplementation on incidence and severity in broilers divergently selected for tibial dyschondroplasia. Poult. Sci., 80:735-740.

QIAN H., VEIT P., KORNEGAY T., RAVINDRAN V., DENBOW M. (1996): Effects of supplemetal phytase and phosphorus on histological and othet tibial bone characteristics and performances of broilers fed semipurified diets. Poult.Sci., 75: 618-626.

RADOVIĆ V., RAJIĆ I., STANIĆ D., NADAŽDIN M. (2003): Uticaj različitih izvora fosfora na telesnu masu i prirast pilića $u$ tovu. Biotehnologija u stočarstvu, 19:43- 47.

REDDISH J., LILBURN M. (2004): A comparison of growth and development patterns in diverse genotypes of broilers. 1. male broiler growth. Poultry Science, 83: 1067-1071.

SU G., SORENSEN P., KESTIN C. (1999) : Meal feeding is more effective than early feed restriction at reducing of leg weakness in broilerchiskens. Poultry Science $78:$ 949-955.

VITOROVIĆ D., ANTONIJEVIĆ N., MAŠIĆ B., PAVLOVSKI Z., SUPIĆ B., STANKOVIĆ J. (1988): Uticaj podnog i baterijskog načina gajenja na dimenzije i čvrstoću kostiju nogu i krila pilića. Peradarstvo, 11-12, 355-357. 
VITOROVIĆ D. (1992) : Anatomske karakteristike kostiju i mišića pilića lakog i teškog tipa gajenih na podu i u kavezima. Doktorska disertacija, Vet.fak., Beohgrad.

VITOROVIĆ D., POPOVOV-RALJIĆ J., MITROVĆ S. (1995): The effect of age and rearing system on bone strength of broiler chicks. Biotehnologija u stočarstvu, 11:21-26.

WHITEHEAD C. (1996) : Nutrition and bone disorders in poultry. XIXth Worlds

Poultry Congress, New Delhi, Indija, 161-171. 